\section{Ceramic composition diversity at Mayapan, the last Maya capital}

\author{
Carmen G. Sánchez Fortoul \\ Department of Anthropology, Florida \\ Atlantic University, Boca Raton, FL, USA
}

\section{Abstract}

This study focuses on the variability of pottery fabrics from Mayapán, the Maya capital during the last pre-Hispanic period (Late Postclassic, A.D. 1200-1519). Traditionally, the materials selected by Late Postclassic potters have been considered a reflection of the carelessness of a decadent society using only what the geology of the region provided. For instance, unlike the variety of inclusions found in the earlier Terminal Classic pottery, Mayapán pottery presents a limited array of raw materials: limestone, the most common rock in the region, is almost the sole inclusion found in its pottery. However, the main mineral in limestone, calcite, is found in nature in a variety of textures. While some fabric analyses have been performed for the pottery of the earlier centres of Chichén Itzá and the Puuc area, analyses targeting the fabrics of Late Postclassic pottery are almost nonexistent. This study aimed to investigate the variability and seek patterns in the fabrics of pottery from Mayapán by performing low-magnification, petrographic, and X-ray diffraction analyses. This study also aimed to clarify associations between fabrics and the local typology. The results revealed multiple fabrics based on the many textural varieties of carbonate rocks. While trends showing the association between types of inclusions and ceramic types were uncovered, no clear-cut correlations between fabrics and typology were observed due to the small sample number. This study also showed that petrographic analysis is an invaluable tool to characterise carbonates in ceramics due to its ability to discern textural variations.

\section{Introduction}

The pottery of Mayapán, the Maya capital during the last pre-Hispanic period or Late Postclassic (A.D. 1200-1519), has been unevenly studied: studies have been overwhelmingly typological, supplemented by some modal analyses, while fabric analyses are scarce. Sedimentary calcareous rocks, such as limestone, dolomitic limestones, and dolostones are the most common rocks in northern Yucatán and the main inclusions in the pottery of Mayapán. That Mayapán’s fabrics have originated little interest is due in part to research that have consistently lumped together nonplastic inclusions under the general term of calcite or limestone, providing little information about the people of this geologically homogeneous region. Smith (1971), for example, characterised Mayapán's paste as strikingly uniform, calcite-tempered, and very homogeneous across all types. The objective of this project was to investigate the variability and underlying patterns of Mayapán's fabrics.

\section{Pottery of Mayapán}

Mayapán's main wares and paste attributes - as described by Smith (1971) who classified them - are summarised in Table 1. In addition to these wares, based on the presence of mono-crystalline calcite, more unslipped wares were defined. Mayapán's pottery evidences a shift from the multiple types of inclusions observed in Terminal Classic pottery - volcanic ash, carbonates, crushed potsherds, and lumpy clay - to the almost exclusive presence of carbonates.

\section{Materials and Methods}

With the aims of this research in mind, this study followed an integrated methodology based on a broad classification refined by petrographic analysis. Two residential Mayapán clusters provided samples for this research. A total of one hundred and twenty nine sherds were selected from some of the main varieties (Table 1) within Mayapán's wares. Given the friable condition and small size of the sherds, a minimum thin section length between twoand-one-half and three $\mathrm{cm}$ ideal for petrographic point-counting was a major consideration during the selection.

The sherds were examined using low magnification (30x) and classified into broad fabric groups. The type-variety classification provided the initial sorting. Sherds were classified further by general type of inclusions and paste colour. From these very broad groups, fifty-two sherds were selected for petrographic analysis of the plastic matrix and inclusions. Six additional sherds from the ceremonial centre were provided by the Instituto Nacional de Antropología e Historia (INAH) for comparison purposes. The plastic matrix and the inclusions were analysed separately and then combined into fabric groups.

The plastic matrix's analysis included four attributes: i) fired paste colour under nonpolarised light; ii) the proportion, calculated during point counting, of micritised skeletal remains or microfossils (intact remains were not observed); iii) the relative abundance of
Correspondence: Carmen G. Sánchez Fortoul, Department of Anthropology, Florida Atlantic University, $6172 \mathrm{NW}$ 88th Ave., Boca Raton, FL 33067, USA

Tel/Fax: +1.954.575.1555.

E-mail: cgs0001@gmail.com

Key words: Maya, Mayapan, fabric analysis, petrography, pottery production.

Citation: Sánchez Fortoul CG, 2013. Ceramic composition diversity at Mayapan, the last Maya capital. In: RH Tykot (ed.), Proceedings of the $38^{\text {th }}$ International Symposium on Archaeometry - May $10^{\text {th }}-14^{\text {th }} 2010$, Tampa, Florida. Open Journal of Archaeometry 1:e4.

Acknowledgments: I would like to thank Dr. Clifford T. Brown of Florida Atlantic University (FAU), Boca Raton, FL, for all his suggestions. I am indebted to Dr. Pedro Corona Chávez, Director of the Instituto de Investigaciones Metalúrgicas, Universidad Michoacana, México, and to Dr. Jasinto Robles Camacho, Laboratorio de Arqueometría del Occidente, Instituto Nacional de Antropología e Historia (INAH), Michoacán, for their collaboration and assistance. Thanks also to Carlos Peraza Lope, INAH, Yucatán, who granted permission to use INAH resources, to the Department of Geosciences, FAU, for the access provided to the petrographic microscopes, and to the Department of Anthropology, FAU, for the funds awarded to this research.

Contributions: the Author, Carmen G. Sánchez Fortoul, takes responsibility for: i) the conception, design, acquisition of data, analysis and interpretation of data; ii) drafting the article and revising this paper; and iii) final approval if this paper.

Conflict of interests: the author declares no potential conflict of interests.

Presented at the $38^{\text {th }}$ International Symposium on Archaeometry - May $10^{\text {th }}-14^{\text {th }} 2010$, Tampa, Florida.

This work is licensed under a Creative Commons Attribution 3.0 License (by-nc 3.0).

(C) Copyright C.G. Sánchez Fortoul, 2013

Licensee PAGEPress, Italy

Open Journal of Archaeometry 2013; 1:e4

doi:10.4081/arc.2013.e4

calcareous crystals less than 10-20 microns in size, or crystallites; and, iv) matrix areas of simultaneous high birefringence colours, or speckled areas. Matthew et al. (1991) comparison charts were used to estimate the abundance of the last two attributes. In addition, a portion of each sherd was re-fired during onehalf hour at $950^{\circ} \mathrm{C}$, higher than the temperature at which Mayapán's pottery is believed to have been fired. 
The petrographic analysis of major inclusions identified, classified, and point-counted non-plastic inclusions in the thin sections. The classification of inclusions was based on Folk's textural classification (Greensmith, 1989; Scoffin, 1987) of limestone: micrite, or mass of calcite crystals each between one and four microns; sparite, or aggregates of crystals each at least 10 microns in size, with some reaching one mm or more; and discrete grains such as peloids and micritised skeletal remains of marine microorganisms. Peloids are dark gray to black, rounded or subrounded grains made of indurated micrite (Adams and MacKenzie, 1998). Dissolution of some peloids in the samples with $\mathrm{HCl}$ showed that they have a bituminous center, suggesting an organic origin.

Next, the thin sections were grouped into clusters with similar proportion of inclusions, using K-means (SPSS) method for clustering (Wards method provided a starting number of clusters to K-means).

X-ray diffraction was performed on five sherds (powder specimens in a Siemens D5000 diffractometer; Siemens, Munich, Germany), for which the fine portion and the coarse grains were separated in order to identify the main minerals present in the clay and inclusions.

\section{Results}

\section{Petrographic analysis}

Due to observed variations in colour and structure, the generic limestone varieties described in the previous section were broken down into sub-classes. Micrite was sub-categorised as either chalky-white or gray (gray and peloidic micrite were lumped together). Two classes of sparite were observed: clear and with a micritic film on the exterior of the grain. Depending on the degree of micritisation, the appearance of micrite-coated sparite grains range from chalky to translucent. Lastly, mono-crystalline forms of calcite and dolomite (identified through staining) were also observed. The use of larger crystalline forms was documented during colonial times. Thompson (1958) cites that in the Pío Pérez Yucatec-Spanish dictionary (based on multiple very early dictionaries, some completed in 1690) the substance called $h i^{\prime}$ is described as a translucent rock which is mixed with clay by the potters for the making of cooking pots. In summary, the petrographic analysis of the major non-plastic inclusions identified chalkywhite micrite, gray/peloidic micrite, clear sparite, micrite-coated sparite, and mono-crystalline forms in Mayapán's pottery clay.

The cluster analysis of inclusions formed clear-cut groups differentiated not by the minerals found but by the dominant presence of one textural variety over the rest. Table 2 contains the groups based on similarity of inclusions and percent abundance.

The re-firing of the sherds showed that a portion of the reddish and brownish fired sherds re-fired to a reddish colour and that another portion re-fired to white, while sherds that originally were fired to very light colours re-fired to white. All re-fired sherds crumbled within $24 \mathrm{~h}$, indicating that the original firing temperature did not reach or stay at $950^{\circ} \mathrm{C}$.

The combined analysis of the plastic matrix attributes and the inclusion-type groups (Table 2) resulted in multiple well-defined fabrics. In order to facilitate the fabrics' description, the following frequency labels will be used: Veryrare $(<=0.5 \%)$, Rare $(>0.5-2 \%)$, Very-few $(>2$ $5 \%)$, Few (>5-10\%), Common (>10-20\%), Frequent (>20-30\%), Abundant (>30-50\%), and Dominant (>50\%).

\section{Fabric 1}

This fabric includes sherds having a matrix that fired to very light colours such as white, yellow-white, very light yellow, very pale browns (Munsell 2.5Y, 10YR; values 7, 8 and chromas $3,4,6,8)$, or light grays; and re-fired to a white colour. Other characteristics of this fabric are the presence of Few peloids, Veryrare to Few skeletal remains, Very-Few crystallites, and speckled areas of optical activity in 20 to $25 \%$ of the thin section's area.

Based on the type and number of non-plastic inclusions, two subgroups to this fabric were identified. One subgroup is dominated by Frequent gray limestone and Few or less of the other inclusions (conforming to the non-plastic inclusions Group II of Table 2). The second subgroup is dominated by sparite or micritecoated sparite (Groups III and VIII of Table 2). This fabric presents the highest abundance of mono-crystalline calcite.

\section{Fabric 2}

This fabric includes sherds that fired red, light red, or reddish yellow to reddish brown (Munsell 5YR, 7.5YR, 10YR; values >4 and

Table 1. Main wares of Mayapán.

\begin{tabular}{|c|c|c|c|}
\hline Wares & Paste inclusions & Decoration & Varieties included in this research \\
\hline Peto Cream & Chalky white limestone; gray limestone & Cream-slipped & Kukula and Xcanchacan \\
\hline Mayapan Black & Chalky white limestone & Brownish-black to black slipped & - \\
\hline Mayapan Unslipped & Chalky white limestone; gray limestone & $\begin{array}{l}\text { Unslipped, smoothed, and never polished; } \\
\text { many lightly striated }\end{array}$ & Yacman and Navula \\
\hline San Joaquin Buff & Chalky white limestone & Buff slipped & Polbox and Tecoh \\
\hline Mayapan Red & Chalky white limestone & Red-slipped & Mama and Unslipped-exterior \\
\hline
\end{tabular}

Table 2. Groups and average percent abundance by inclusion type.

\begin{tabular}{|c|c|c|c|c|c|c|c|c|}
\hline \multirow[t]{2}{*}{ Group } & & & & \multicolumn{5}{|c|}{ Inclusion type } \\
\hline & I & II & III & IV & V & VI & VII & VIII \\
\hline White micrite & 21 & 4 & 3 & 13 & 37 & 7 & 3 & 3 \\
\hline Gray micrite & 4 & 23 & 3 & 1 & 4 & 12 & 2 & 6 \\
\hline Clear sparite & 5 & 3 & 13 & 24 & 3 & 2 & 1 & 2 \\
\hline Coated sparite & 4 & 6 & 9 & 13 & 4 & 5 & 43 & 19 \\
\hline Monocrystal & 3 & 0 & 8 & 1 & 0 & 1 & 2 & 1 \\
\hline
\end{tabular}


chroma $>3$ ); and re-fired to red or reddish colours. Other characteristics of this fabric are the absence of peloids, negligible to around 5$10 \%$ micritised skeletal remains, and speckled areas in 20 to $25 \%$ of the thin section's area. In some areas the matrix consists of faint interlocking rhombohedral outlines.

Based on the inclusions, there are two subgroups to this fabric. In one subgroup, the fabric presents Frequent to Abundant subrounded and angular fragments of chalky-white micrite and Very-Few of the rest of inclusions (corresponding to Groups I and V in Table 2). The second group is dominated by Frequent to Abundant micrite-coated sparite (Group VII and VIII) and, in some cases, also presenting semi-translucent fragments of sparite and clear mono-crystalline forms of calcite (Groups III and IV).

\section{Fabric 3}

Included in this fabric are sherds that fired red, light red, or reddish yellow to reddish brown (Munsell 5YR, 7.5YR, 10YR; values $>4$ and chroma $>3$ ); and re-fired to white colours. The fabric presents Very-rare microfossils and peloids. Speckled areas occupy around $20 \%$ of the thin section's area. Regarding the inclusions, they seem similar to the ones in Fabric 2 , but not much can be said about their patterns due to the small number of samples in this fabric.

\section{Fabric 4}

This fabric includes sherds that fired into the browns from light brown to yellowish brown colours (Munsell 10YR, 2.5Y; values 5-7, chroma 3,4,6,8) or olives (Munsell 7.5YR; values 5,6; chroma 3,4), re-fired to reddish colours, and presented a matrix characterised by the absence of crystallites, skeletal remains, Very-few peloids, and speckled areas in around 10 percent of the thin section's area.

This fabric includes two subgroups. In one subgroup chalky-white micrite dominates, containing from Frequent to Abundant amounts of white micrite and Very-few of the rest (conforming to Groups I and V of Table 2). Frequent gray limestone dominates the second group containing Few or less of the other inclusions (conforming to Group II of Table 2).

\section{Fabric 5}

This fabric includes sherds that fired into the browns from light brown to yellowish brown colours (Munsell 10YR, 2.5Y; values 5-7, chroma 3,4,6,8) or olives (Munsell 7.5YR; values 5,6; chroma 3,4 ), and re-fired to white colour. This fabric is opaque under polarised light, with Common presence of peloids and absence of skeletal remains, speckled areas, calcareous prisms outlines, crystallites, or individual prisms floating in the matrix. The inclusions are primarily Common to Frequent gray limestone and Few or less of the other inclusions (conforming to Group II of Table 2).

\section{X-ray diffraction}

All XRD samples presented a very homogeneous mineral composition (Table 3 ). The clay matrix contained palygorskite and calcite. Halite $(\mathrm{NaCl})$ was also present in the matrix of three of the five samples. The coarse inclusions are either calcite or calcite and ferroan dolomite.

\section{Discussion}

\section{The fabric}

Palygorskite was the only clay found in this research's XRD samples. This result can be explained by Sánchez del Río et al.'s (2009) analysis of multiple (19) palygorskite samples from an area located 20 miles south-west of Mayapán that showed that palygorskite is common in the area, found at almost surface area, and that in any of the samples palygorskite is found in combination with other clays.

The role of palygorskite as pottery clay or temper is difficult to assess. Within Mayapan's general area, the use of palygorskite by modern potters greatly differs. Other studies around the towns of Ticul and Sacalum found that the use of palygorskite is mostly restricted to tempering, while an ethnographical and mineralogical study of clays used by local potters ( $k$ 'an k'at o yellow clay to build large pieces and chak k'at or red clay used for smaller pieces) from the town of Mama showed that palygorskite was used as pottery clay. In addition, Sánchez del Río et al. (2009) study found that their two samples of the substance locally known as sascab and used as temper by modern potters, although usually described as unconsolidated limestone, were made of palygorskitic marls containing palygorskite with calcite and/or dolomite.

The origin of the very fine calcite crystallites in the matrix, particularly in Fabrics 1 and 2 is unclear. Crystallites and coarser sparite bundles seem to co-occur and the size of each crystallite and the crystals that form the sparite bundles are similar. This suggests that the crystallites resulted from either the grinding the sparite fragments or the depletion of sparite fragments found in the clay, and not from the use of limestone grinding tools as it has been suggested.

Table 3 shows that the main inclusions in the XRD samples are made of calcite and ferroan-dolomite. Given that re-firing at $950^{\circ} \mathrm{C}$ turned white all the calcareous inclusions, it can be affirmed that the colour in the gray or peloidic limestone is due to organic material. Given the presence of calcite, the co-occurrence of salt (halite; Table 3) in the matrix deserves further investigation. The experimental work by researchers such as Stimmell

Table 3. X-ray diffraction results.

$\begin{array}{lccc}\text { Analysed portion } & \text { Appearance at } & \text { Sample } & \text { Minerals found (XRD) } \\ \text { low-magnification } & & \text { Calcite, Palygorskite } \\ \text { Plastic matrix } & \text { Clay matrix } & \text { Halite, Palygorskite } & \text { Halite, Calcite, Palygorskite } \\ & \text { Clay matrix } & \text { Clay matrix } & \text { Halite, Calcite, Palygorskite } \\ \text { Clay matrix } & \# 133 & \text { Calcite } \\ \text { Inclusions } & \text { Clear prismatic grain } & \# 82 & \text { Calcite, Ferroan-dolomite } \\ & \text { Micrite-coated sparite } & \text { Calcite, Ferroan-dolomite } & \text { Calcite } \\ \text { White-chalky and sparite grains } & \text { Calcite } \\ \text { Micrite-coated sparite grain } & \text { White-chalky grain } & \text { Cray grains } & \text { Calcite, Ferroan-dolomite } \\ & \text { Gray grains } & \text { Calcite }\end{array}$

XRD, X-ray diffraction; \#60, Calcite-temp-unslipped variety; \#133, Tecoh (ceremonial center); \#82, Yacman; \#15, Yacman; \#59, Calcite-temp-unslipped. 
Table 4. Association of major inclusions groups and typology.

\begin{tabular}{|c|c|c|c|c|c|c|}
\hline \multirow[t]{2}{*}{ Group } & \multirow{2}{*}{$\begin{array}{l}\text { Group's main } \\
\text { inclusion }\end{array}$} & \multicolumn{2}{|c|}{ Mayapán Red ware } & \multicolumn{2}{|c|}{ Mayapán Unslipped ware } & \multirow{2}{*}{$\begin{array}{c}\text { Peto Cream ware } \\
\text { Kukula }\end{array}$} \\
\hline & & Mama & Unslipped exterior & Yacman & Navula & \\
\hline $\mathrm{I}, \mathrm{V}$ & Chalky-white-micrite & $X$ & & & $X$ & \\
\hline II & Grey limestone & $\mathrm{X}$ & & X & & $\mathrm{X}$ \\
\hline IV & Clear sparite & & & $\mathrm{X}$ & & \\
\hline VII, VIII & Coated-sparite & & $X$ & $\mathrm{X}$ & $\mathrm{X}$ & $\mathrm{X}$ \\
\hline III & arite and mono-crystals & & $\mathrm{X}$ & $\mathrm{X}$ & & \\
\hline
\end{tabular}

et al. (1982) has showed that, in order to avoid the ceramic defects (popping, spalling, even crumbling) that come with calcite decomposition to lime (calcinations), the firing temperature has to be either controlled to less than $700^{\circ} \mathrm{C}$ or salt (halite or $\mathrm{NaCl}$ ) has to be present by adding it or by using clay naturally high in salt content.

\section{Residential area samples}

Although the inclusion-type groups run across multiple ceramic types, some inclusions are more prevalent in certain ceramic types. This is reflected in Table 4 that shows the association of inclusion-type groups (Table 2) and typology. For example, in sherds of the Mama variety, chalky-white micrite dominates, while in the Yacman variety (unslipped jar thought to be a cooking pot) gray and clear forms of calcite dominates.

Due to the small sample size, little can be said about the associations between ceramic typology and the fabrics: Mama sherds predominately belonged to Fabric 2 (reddish fired and re-fired colour, micritised skeletal remains, rare peloids, and inclusions dominated by chalky-white micrite); and Kukula shreds were mostly associated to Fabric 5 (opaque with brownish fired and white refired colours, absence of micritised remains and crystallites, high incidence of peloids, and gray limestone as main inclusion). Future research with larger numbers of samples should address these associations.

\section{Comparison residential and ceremonial centre}

The samples from the ceremonial centre did not fit into the compositional groups or fabrics described earlier for the residential area: they contained unusually high amounts of monocrystalline calcite (20-40\%) or semi-translucent sparite (30\%). Similarly, one Mama sherd contained unusually high amounts (40\%) of micrite-coated sparite.

\section{Conclusions}

This study shows that Mayapan's pottery presents multiple fabrics based on the textures of carbonate rocks, and that there are associations between these textures and the local ceramic types. Future research could use a larger sample to better define these associations. The presence of salt in the matrix potentially increases the level of variety and skills reflected in the pottery. The nature and extent of this practice in the archaeological material deserves further investigation. In sum, this study showed that petrographic analysis is an invaluable tool that increased the information about the people from such a geologically homogenous region as northern Yucatán.

\section{References}

Adams AE, MacKenzie WS, 1998. A colour atlas of carbonate sediments and rocks under the microscope. Manson Publ., London, UK.

Greensmith JT,1989. Petrology of sedimentary rocks. $7^{\text {th }}$ ed. University Printing House, Oxford, UK.

Matthew AJ, Woods AJ, Oliver C, 1991. Spots before the eyes: new comparison charts for visual percentage estimation in archaeological material. In: Middleton A, Freestone I (eds.), Recent developments in ceramic petrology. British Museum Press, London, UK, pp 211-254.

Sánchez del Río M, Suarez M, García-Romero E, 2009. The occurrence of palygorskyte in the Yucatán peninsula: ethno-historic and archaeological contexts. Archaeometry 51:214-30.

Scoffin TP, 1987. An introduction to carbonate sediments and rocks. Chapman and Hall ed., New York, NY, USA.

Smith RE, 1971. The pottery of Mayapan: including studies of ceramic material from Uxmal, Kabah, and Chichén Itzá. Harvard University ed., Cambridge, MA, USA.

Stimmell C, Heimann RB, Hancock RGV, 1982. Indian pottery from the Mississippi valley: coping with bad raw materials. In: Olin JS, Franklin AD (eds.), Archaeological ceramics. Smithsonian Institution Press, Washington, DC, USA, pp 219-228.

Thompson RH, 1958. Modern Yucatecan Maya pottery making. The Society for American Archaeology ed., Salt Lake City, UT, USA. 